\title{
Notes
}

\section{Requiring Due Care in the Process of Patient Deinstitutionalization: Toward a Common Law Approach to Mental Health Care Reform}

\author{
Jonathan P. Bach
}

Over the past three decades, many patients formerly treated in large state mental institutions have been released or transferred to community settings where, presumably, they are able to receive less restrictive, more humane care. " The consequences of this process of "deinstitutionalization" have become one of the most significant concerns of American mental health care policy. Due to a lack of adequate community services and facilities to accommodate the emergent, rapidly increasing outpatient population, ${ }^{2}$ many former patients are now located in inappropriate housing and receiving substandard care ${ }^{3}$-or, at the extreme, are homeless and receiving no care at all. Although deinstitutionalization has often led to

1. See generally Bassuk \& Gerson, Deinstitutionalization and Mental Health Services, Scr. AM. Feb. 1978, at 46; Kanter, A Brief History of Deinstitutionalization, in 1 ProteCTION \& ADvocACY for People Who Are Labeled Mentally Ill 79 (Mental Health Law Project ed. 1987).

2. See Community Support for Mental Patients: Hearings on Programs in the Community for Chronically Mentally Ill Adults Before the Subcomm. on Health and the Environment of the House Comm. on Interstate and Foreign Commerce, 96th Cong., 1st Sess. 2-3, 26 (1979) (statements of Reps. Waxman \& Mikulski) [hereinafter Community Support Hearings]; General Accounting Office, Returning the Mentaliy Disabled to the Community: Government Needs to DO MORE 1-8 (1977).

3. Much of the outflow has led to reinstitutionalization in nursing homes, large board and care facilities, prisons, and jails. Goodman, Adams, \& Taube, Deinstitutionalization: The Data Demythologized, 34 Hosp. \& Community Psychiatry 129 (1983).

4. Current studies indicate that approximately $30 \%$ of the homeless are mentally ill. The mentally ill are at high risk of becoming and remaining homeless because of their functional disabilities, and 
successful reintegration in transitional living situations or group homes, the gaps in the system have provoked critical reassessment of the conditions many patients confront upon release. In order to facilitate a more successful process of large-scale patient release, critics of the present system have begun to explore legal means to improve post-discharge environments.

The possibility of pursuing legal remedies has been effectively foreclosed at the federal level. Current interpretations of the Eleventh Amendment severely limit the opportunity to bring cases against state mental institutions in federal court. ${ }^{5}$ Moreover, the Supreme Court's recent, unanimous decision in Youngberg $v$. Romeo recognized only minimal rights of mentally disabled persons under the federal constitution. ${ }^{6}$ As a result, state courts and legislatures have now become the principal fora for determining the rights of the mentally ill. ${ }^{7}$ Advocates and scholars have begun an intensive analysis of state constitutions and statutes, ${ }^{8}$ and some have begun to consider the common law. ${ }^{9}$ Common law doctrine has already been successfully employed, for example, in securing the right of mentally ill patients to refuse treatment. ${ }^{10}$

This Note considers the possibility of using the common law of torts to promote reforms in the patient discharge process and in the subsequent provision of community care. It will argue that the common law can address some of the clearest and most significant examples of negligence that

deinstitutionalization has been perceived as one of the most significant contributors to homelessness. See R. HAyes, The Rights of THe Homeless 509-10 (1987); Levine \& Stockdill, Mentally Ill and Homeless: A National Problem, in Treating the Homeless: Urban Psychiatry's ChalLENGE 1-16 (B. Jones ed. 1986).

5. See Pennhurst State School \& Hosp. v. Halderman, 465 U.S. 89 (1984) (Eleventh Amendment precludes enforcement by federal court of state law against state officials); Clark v. Cohen, 794 F.2d 79, 98 (3d Cir. 1986) (Becker, J., concurring) ("[T] he state could release someone to whom it owed a grave obligation, and then hide behind its eleventh amendment shield to avoid that obligation.").

6. 457 U.S. 307 (1982). In Youngberg, an institutionalized mentally retarded person, often put in mechanical restraints because of his violent tendencies, brought an action through his mother against the state. While the Court held that the patient had a right to training in basic self-care skills, it recognized a constitutional obligation to provide only that minimum amount that would enable him to avoid danger and unnecessary restraint. Id. at 319. Although the Court also recognized that institutionalized patients maintained "liberty interests" in adequate food, shelter, clothing, medical care, safety, and freedom of movement, it recognized none of these rights as "absolute" and left their content to be determined by "professional judgment." Id. at 319-21. The implications of Youngberg have been a matter of some debate. See, e.g., Note, The Constitutional Right to Treatment in Light of Youngberg v. Romeo, 72 GEo. L.J. 1785 (1984) (summarizing Department of Justice's narrow interpretation of Youngberg and suggesting broader approach).

7. Miller, Rachlin, \& Appelbaum, Patients' Rights: The Action Moves to State Courts, 38 HosP. \& Community Psychiarry 343 (1987); Perlin, State Constitutions and Statutes as Sources of Rights for the Mentally Disabled: The Last Frontier?, 20 LoY. L.A.L. REv. 1249 (1987).

8. Meisel, The Rights of the Mentally Ill Under State Constitutions, 45 LAw \& CoNTEMP. ProBs. 7 (1982); see supra note 7.

9. See Meisel, supra note 8, at 36-39; Note, A Common Law Remedy for Forcible Medication of the Institutionalized Mentally Ill, 82 CoLUM. L. REv. 1720 (1982); see also infra note 65 (discussing current common law causes of action).

10. See, e.g., Rogers v. Commissioner, 309 Mass. 489, 458 N.E.2d 308 (1983); Rivers v. Katz, 67 N.Y.2d 485, 495 N.E.2d 337, 504 N.Y.S.2d 74 (1986). 
arise as patients are released. Specifically, common law tort doctrine can remedy the many instances in which patients have been discharged directly to city streets, without shelter or supervision, after the hospital has made no significant attempt to arrange for some form of continuing community support. ${ }^{11}$ The recognition of liability in such cases would establish a doctrinal base which subsequent common law rulings could incrementally extend to address other more subtle forms of abuse. Findings of liability could also prompt further legislative action aimed toward securing a more adequate provision of community care.

Part I of this Note will briefly summarize the history of deinstitutionalization. Part II will argue that, in the absence of sufficient constitutional and statutory remedies, the common law must be explored as the most effective legal alternative available to address aspects of the transition to community care that need to be improved. Part III will develop a common law tort theory of negligent patient release. Part IV will consider the range of probable legislative and institutional responses to common law rulings that recognize governmental liability where patients have been released to inadequate environments. This Note will conclude that the common law offers a gradual but valuable means for responding to and mitigating some of the most significant problems that have so far prevented a successful process of patient deinstitutionalization.

\section{Deinstitutionalization: History and Gritique}

With the development of antipsychotic drugs in the early 1950's and the emergence of a humanitarian philosophy of mental illness, thousands of patients left the confines of large state mental hospitals for the first time. ${ }^{12}$ President Kennedy succeeded in marshalling the first federal support for community treatment alternatives through the Mental Retardation and Community Health Centers Construction Act of 1963, which envisioned a nationwide network of Community Mental Health Centers (CMHCs) ${ }^{13}$ The specific goal of the Act was to reduce state hospital populations by fifty percent within two decades, and federal funds were to be granted to all CMHCs that provided several essential services. ${ }^{14}$ Legislatures were attracted by the fiscal efficiencies of reduced institutional treatment, and a series of judicial decisions helped to define the constitutional basis for what promised to be a new, enlightened form of care. ${ }^{15}$ Between 1955 and

11. See infra note 25 (discussing negligent release to city streets).

12. See Kanter, supra note 1, at 81; Rhoden, The Limits of Liberty: Deinstitutionalization, Homelessness, and Libertarian Theory, 31 EMORY L.J. 375 (1982).

13. Pub. L. No. 88-164, 77 Stat. 282 (1963), repealed by Pub. L. No. 97-35 § 902(e)(2)(b), 95 Stat. 560 (1981).

14. Kanter, supra note 1 , at $81-82$.

15. Two of the most noted cases are Wyatt v. Stickney, 325 F. Supp. 781, 784 (M.D. Ala.) (first recognizing right of involuntarily institutionalized patients to receive "such individual treatment as will give each of them a realistic opportunity to be cured or to improve his or her mental condition"), 
1980 , the number of patients in state mental hospitals dropped from 559,000 to $132,000 .^{16}$ This exodus has been termed "deinstitutionalization." The term also refers to the discharge of individual patients.

In essence, deinstitutionalization was intended to achieve two related yet independent goals: a decrease in inpatient populations as placement shifted to less restrictive settings, and a corresponding increase in the provision of mental health care in the community. ${ }^{17}$ While the value of treating patients in less restrictive settings has continued to receive widespread support, criticism has focused on the failure to achieve the second of these goals, contending that state officials have yet to make deinstitutionalization work at the community level. While hospital populations have been rapidly depleted, community care facilities have not been developed in numbers adequate to accommodate the massive patient release. ${ }^{18}$ Of the 2,500 planned federally supported CMHCs, fewer than 700 have been established, serving only half the nation. ${ }^{19}$ The initial federal grants expired, and additional sources of revenue have not been forthcoming. ${ }^{20}$ Those funds that do exist are disproportionately allocated in favor of institutional treatment instead of community care. Despite tremendous reductions in chronic hospital populations, state hospitals continue to receive the vast majority of state mental health budgets, with few resources left over for community alternatives intended to serve far greater numbers of patients. ${ }^{21}$

Where they have been established, community facilities tend to be frag-

334 F. Supp. 1341 (M.D. Ala. 1971), 344 F. Supp. 373 \& 387 (M.D. Ala. 1972), affd in part and remanded in part sub nom. Wyatt v. Aderholt, 503 F.2d 1305 (5th Cir. 1984); and O'Connor v. Donaldson, 422 U.S. 563 (1975) ("no constitutional basis for confining [mentally ill] persons if they are dangerous to no one and can live safely in freedom"); see also Rapson, The Right of the Mentally Ill to Receive Treatment in the Community, 16 ColvM. J.L. \& Soc. Pross. 193, 203-06 (1980) (discussing legislative and judicial developments).

16. Kanter, supra note 1 , at 79 .

17. See id. at 79-82.

18. Costello \& Preis, Beyond Least Restrictive Alternative: A Constitutional Right to Treatment for Mentally Disabled Persons in the Community, 20 Loy. L.A.L. Rev. 1527 (1987); Rapson, supra note 15, at 193-200; see also sources cited supra note 2.

19. 2 Task Panel Reports Submitted to the President's Commission on Mental. Health 319 (1978).

20. See Kanter, Overcoming Obstacles to Housing for People Who are Mentally Disabled and Homeless, in 2 Protection \& Advocacy for People Who Are Labeled Mentally Ill, supra note 1 , at 955 .

21. State hospitals receive more than twice the funds allocated to CMHCs under state budgets. See Rubenstein, Access to Treatment and Rehabilitation for Severely Mentally Ill Poor People, 20 Glearinghouse Rev. 382, 383-89 (special issue, summer 1986). In Texas, for example, state hospitals continue to receive nearly $80 \%$ of all mental health funds, even though their populations have been reduced by more than two thirds. Nocera, The Long, Lonesome Road, 14 TEx. MoNTHLy 134, 136 (Nov. 1986). In 1965, New York State had 85,000 patients in state psychiatric facilities, but in 1979 it had only 25,000 . At both times, $80 \%$ of state funds were allocated to state psychiatric facilities as opposed to community alternatives. OfFICE of THE PRESIDENT OF THE NEw YORK CrTY CoUNcil, From Country Asylum to City Streets: The Contradiction Between Deinstitutionalization and State Mental Health Funding Priorities 1 (1979); see also infra note 41 and accompanying text (discussing political factors influencing funding patterns). 
mentary and fail to integrate and coordinate their services. ${ }^{22}$ Patients find themselves in complex urban environments where appropriate housing is hard to find and retain. Many patients are routinely discharged to substandard boarding houses and nursing homes that lack psychiatric care. ${ }^{23}$ Often, after a series of moves and displacements, their mental conditions deteriorate and some become homeless. ${ }^{24}$ In worse cases, patients have been released from institutions directly to city streets without written discharge plans or any other provisions for shelter, supervision or basic community support. ${ }^{25}$ Proponents of deinstitutionalization are among those most critical of the shortage of adequate facilities and services. Accordingly, they have turned to legal remedies to improve the process of transition to community care.

\section{The Limted Utility of Constitutional and Statutory Alternatives}

In light of the limited rights recognized by the Supreme Court in Youngberg and other indications that the federal judiciary will no longer play a dominant role in overseeing patient rights, mental health advocates have shifted their attention to constitutional and statutory provisions at the state level..$^{2 B}$ Constitutions and statutes are the foremost embodiments of American law; both are superior to and may supplant or abrogate the common law. They thus offer, at least in theory, the strongest possible bases of reform. However, state constitutions and statutes have so far been, and are likely to remain, very limited in their ability to address the inadequacies in community care now confronting large numbers of the deinstitutionalized mentally ill. This does not mean that constitutions and statutes should be abandoned as possible sources of reform-far from it. It means only that their weaknesses should be frankly acknowledged and

22. "[N]o agency at any level, public or private, has undertaken responsibility for coordinating funding, treatment, and care for the chronically ill." Talbott \& Sharfstein, A Proposal for Future Funding of Chronic and Episodic Mental Illness, 37 Hosp. \& Communiry Psychiatry 1126, 1128 (1986); see Rapson, supra note 15, at 210-13.

23. Bassuk \& Gerson, supra note 1, at 50; see also supra note 3 (discussing reinstitutionalization).

24. Caton \& Goldstein, Housing Change of Chronic Schizophrenic Patients: A Consequence of the Revolving Door, 19 Soc. Scr. MED. 759 (1984); Bassuk \& Gerson, supra note 1, at 50; see also supra note 4 (discussing homelessness).

25. By the early 1970's, the "dumping" of patients onto the streets without any community care at all had become a common practice. Community Support Hearings, supra note 2, at 26 (statement of Rep. Mikulski); Reich \& Segal, The Emergence of the Bowery as a Dumping Ground, 50 PsYCHoLogy Q. 191 (1978); Rubenstein, supra note 21, at 384; Lawsuits Fault the Discharge of Mentally Ill: Assert New York Fails to Draft Follow-up Plans, N.Y. Times, Oct. 28, 1987, at B3, col. 6.

26. See supra notes 7-8. Following the landmark decision in Wyatt v. Stickney, 325 F. Supp. 781 (M.D. Ala. 1971), federal litigation was used increasingly as a means to achieve mental health reforms. However, "[i]t is now clear that the initial efforts to change mental health systems through litigation at the federal level have failed." Santiago, Gittler, Beigel, Stein \& Brown, Changing a State Mental Health System Through Litigation: The Arizona Experiment, 143 AM. J. Psychiarry 1015 (1986). 
that alternative remedies should be seriously explored as valuable supplements to these principal legal tools.

\section{A. Problems Inherent in State Constitutional Approaches}

Few state constitutional decisions accord rights to the mentally ill. ${ }^{27}$ "In many states, the use of state constitutions to enforce civil rights is a relatively new phenomenon." ${ }^{28}$ Faced with this dearth of precedent, state courts will rely heavily on federal decisions to interpret their own constitutions. ${ }^{29}$ In other words, they are likely to inherit many of the doctrinal constraints currently preventing federal courts from undertaking a more reformist constitutional stance.

Constitutional analysis of the rights of mentally disabled persons, whether at the state or federal level, has been largely premised on what courts have termed a theory of "quid pro quo." 30 According to such a theory, the government is under no obligation to provide care to disabled persons unless it has deprived them of some fundamental right. Where a deprivation has occurred as a result of state action, the state must provide some benefit in return. For example, in the case of an involuntarily institutionalized mentally ill person, the government is constitutionally bound to provide minimal treatment services in exchange for the denial of liberty entailed by mandatory confinement. While this formulation has enabled many courts to recognize the rights of those in confinement, ${ }^{31}$ it has at the same time prevented them from establishing a constitutional basis for recognizing the rights of former patients currently situated outside of institutional walls where, presumably, no deprivation of liberty occurs. ${ }^{32}$ Standard constitutional analysis, when applied at the state level, will have to overcome this doctrinal constraint in order to yield affirmative rights in the post-discharge environment. ${ }^{33}$

27. Perlin, supra note 7 , at $1275,1292-93$.

28. Costello \& Preis, supra note 18 , at 1537.

29. Id.; Perlin, supra note 7, at 1275; see also Developments in the Law-The Interpretation of State Constitutional Rights, 95 HARv. L. REv. 1324, 1493-94 (1982) (state constitutional interpretation largely influenced by federal precedents).

30. Judge Becker summarized the quid pro quo theory in his concurrence in Clark v. Cohen, 794 F.2d 79 (3d Cir. 1986). Because the mentally disabled person, unlike the criminal, has done nothing wrong, "involuntary commitment is therefore constitutionally problematic, and to justify it the state must give the civilly committed persons something in exchange for their loss of liberty. . . . Habilitation is the constitutionally required quid pro quo for civil confinement, hence the name of the theory." Id. at 93-94; see also Donaldson v. O'Connor, 493 F.2d 507, 522 (5th Gir. 1974) ("there must be a quid pro quo extended by the government to justify confinement"), vacated, 422 U.S. 563 (1975).

31. See, e.g., Youngberg v. Romeo, 457 U.S. 307 (1982) (discussed supra note 6); Wyatt v. Stickney, 325 F. Supp. 781 (M.D. Ala. 1971) (discussed supra note 15).

32. According to Judge Becker, "it would appear that by its very nature the quid pro quo theory supports a right to habilitation only during the time of actual civil involuntary commitment." 794 F.2d at 98 n.13 (Becker, J., concurring). Some rights may be recognized where patients have been involuntarily committed to community settings, rather than simply released from the hospital. See infra notes 34-36 and accompanying text.

33. While the quid pro quo theory provides the predominant doctrinal basis for analyzing the constitutional rights of mentally disabled patients, it is not the only constitutional theory available for 
Constitutional doctrine has evolved to the point where some decisions have recognized the right of patients to be committed to community residences where professional judgment deems it appropriate. ${ }^{34}$ However, even these decisions do not constitute a departure from traditional quid pro quo analysis. The patients remain wards of the state, with their liberty constrained, regardless of whether they are physically located in a hospital or in a community residence with similar rules. ${ }^{35}$ To this day, no decision recognizes the constitutional right of a released, non-committed mentally ill person to receive aftercare support in the community. In fact, two federal circuits have held, unequivocally, that institutionalized mentally disabled patients have no constitutional right to placement in the community for treatment. ${ }^{36}$

Another difficulty involved in employing constitutional sources of law lies in their potentially decisive impact. A constitutional decision may override or supplant state statutes and thus confront legislatures, forcing them to abide by judge-made law instead of allowing them to develop their own flexible solutions to a complex problem. ${ }^{37}$ The common law approach is in this sense more desirable than constitutional alternatives, for it enables courts to intervene resolutely and persistently without completely overthrowing legislative discretion and priorities. ${ }^{38}$

Working with a complicated and delicate issue of first impression, state courts will be generally reluctant to order state officials to comply with newly articulated state constitutional rights. ${ }^{39}$ In the absence of a clear constitutional mandate - of a kind that does not exist-courts will hesitate to constitutionally impose improved standards for deinstitutionalization.

determining such rights. However, other theories are less well developed and seem even less likely to generate community treatment rights. For instance, Judge Becker discusses the alternative of a parens patriae theory of care, according to which the state must provide the care implicit in the role of parens (or parent) for patients it has institutionalized precisely because they are unable to care for themselves. See id. at 94-95 (Becker, J., concurring). Yet, "the Supreme Court has not had occasion specifically to address this theory of a state's obligations to those it commits pursuant to its parens patriae power," and the lower federal court cases construing the theory have so far involved only the provision of treatment within institutions. Id. at 95 . Becker speculates that the right of a released patient to obtain care in the community could be "compatible" with a parens patriae theory. Id. at 98 n.13. But no court has issued a decision that supports this view, and it seems plausible that a state could fulfill its parens patriae duty simply by providing adequate treatment within the institution, regardless of what befalls the patient once he or she is released.

34. See Clark v. Cohen, 794 F.2d 79 (3d Cir. 1986); Thomas S. v. Morrow, 781 F.2d 367 (4th Cir. 1986).

35. See Clark, 794 F.2d at 97 (Becker, J., concurring).

36. See Society for Good Will to Retarded Children v. Cuomo, 737 F.2d 1239 (2d Cir. 1984); Phillips v. Thompson, 715 F.2d 365 (7th Cir. 1983).

37. "Once the courts have modified or invalidated a statute on constitutional grounds, they have done much more than act in an area of legislative inertia. . . . [T]heir use of constitutional adjudication makes legislative correction of their mistake impossible." G. CALABRESI, A Common LAW FOR THE AGE OF STATUTES 11 (1982).

38. Comparing constitutional and common law, Dean Calabresi observes: "The consequence of a wrong guess is not merely legislative revision, as in common law adjudications; a wrong guess will entail either a constitutional amendment or the dominance of judge-made law." Id.

39. See Costello \& Preis, supra note 18, at 1537. 


\section{B. Problems Inherent in State Statutory Approaches}

Statutory remedies are limited by the nature of the legislative process. The mentally ill lack the constituency necessary to effect majoritarian reform. ${ }^{40}$ Moreover, powerful constituencies have organized to resist the development of community care. ${ }^{41}$ Where statutes have been created despite these obstacles, they often contain only vague language with no direct mandate for the development of community services. ${ }^{42}$ In cases where statutes have provided specifically for the development of comprehensive community facilities, legislative standards have been superseded by legislative funding allocations reflecting different goals. Courts have interpreted legislative failure to provide sufficient funds as evidence of legislative intent to create a mere precatory statute, rather than a mandatory law..$^{43}$

Since it is unlikely that legislatures will develop appropriate remedies, when no influential group exists to press for their enactment, only judicial attention offers some promise of reform. Constitutional solutions are not forthcoming. Practically speaking, therefore, attention must be focused on the common law as a means for courts to undertake their traditional role

40. Chayes, The Role of the Judge in Public Law Litigation, 89 Harv. L. REv. 1281, 1315 (1976).

41. Many neighborhood groups, often referred to as NIMBY ("not in my backyard"), have organized against the creation of transitional housing for mentally ill people in their communities. See Combatting NIMBY, 18 Clearinghouse Rev. 515 (1984); $c f$. N.Y. Times, Jan. 7, 1988, at A26, col. 1. (editorial on transitional housing for homeless) ("The word of the year in 1987 was probably Nimby."). Moreover, towns and labor unions that have become financially dependent on large institutions have exerted pressure to limit the transfer of funds to cities where most of the mentally ill have gone to live. Mental Health on the Street, N.Y. Times, Jan. 25, 1988, at A22, col. 1 (editorial).

42. Only fourteen states have statutes that encourage or require treatment of the mentally ill in the least restrictive environment. Only two of these create a certain entitlement to community services or deinstitutionalization. See Colo. Rev. Stat. § 27-10-101(a)-(b) (1982); Wis. Stat. ANN. § 51.61(1)(e) (West 1987). The District of Columbia created a similar entitlement by judicial interpretation. See Dixon v. Weinberger, 405 F. Supp. 974, 979 (D.D.C. 1975). Georgia makes it state policy to secure the least restrictive alternative placement. GA. CODE ANN. §37-3-161 (1982). Six of the fourteen provide an indeterminate right to treatment in the least restrictive setting. See ALASKa StAT. $\S 47.30 .655$ (2) (1984); CAL. WeLFARE \& INST. CODE § 5325.1(a) (West 1984); Ill. ANN. Stat. ch. 91 1/2, para. 2-102(a) (Smith-Hurd 1987); ME. Rev. Stat. ANN. tit. 34-B, \$ 3601-06 (Supp. 1988); Mo. Ann. Stat. § 630.115.1(10) (Vernon 1988); PA. Stat. AnN. tit. 50, § 7102 (Purdon Supp. 1988). Hawaii and Vermont both support deinstitutionalization or community services indirectly. See Haw. Rev. Stat. § 334-35(1), (3) (1968); VT. Stat. ANN. tit. 18, §7703 (1987). Massachusetts and Minnesota have a procedure for reviewing alternatives to hospitalization. Mass. GEN. LAws AnN. ch. 123, § 4(3) (West Supp. 1988); MinN. Stat. ANN. § 253B.09(1) (West Supp. 1988). Thirty-six states lack a statutory framework acknowledging a right to mental health treatment in the least restrictive available setting for mentally ill patients. See generally S. BRAKEL, J. PARRY \& B. Weiner, The Mentally Disabled and THE LAW 626-28 (1985) (describing statutory frameworks). New York law requires that the released patient be provided a written discharge plan. N.Y. Mental Hyg. LaW $\$ 24.15$ (g) (McKinney 1988).

43. See, e.g., Mental Health Ass'n v. Deukmejian, 186 Cal. App. 3d 1450, 233 Cal. Rptr. 130 (1986) (statutory scheme indicated only legislative preference for community-based treatment, not mandatory right, because state mental health budget was not substantially increased at time legislation was enacted) (opinion ordered unpublished, Mar. 5, 1987); of. Rodgers v. Gibson, 218 N.J. Super. 452,528 A.2d 43, 46 (1987) (despite apparent mandate of existing laws, programs for homeless presently not adequately funded). 
in protecting individual rights and in urging greater responsiveness on the part of government and community bodies.

\section{A Common Law Theory of Negligent Patient Release}

Common law courts have sufficient authority and doctrine to counterbalance constituencies that favor the status quo. The doctrinal basis of their authority lies both in fundamental tort law and in specific precedents in medical malpractice and the mental health care field. One of the most important features of the common law approach that distinguishes it from other legal alternatives is that it recognizes a continuing duty of care that extends beyond the technical termination of the patient's institutional stay and accompanies his or her return to the community. This duty could be employed as an effective legal means for refining the process of deinstitutionalization and for guaranteeing better access to community care.

\section{A. Fundamental Tort Doctrine}

"It is ancient learning that one who assumes to act, even though gratuitously, may thereby become subject to the duty of acting carefully, if he acts at all."'\$4 Thus, for example, a good samaritan, though not initially obligated to render aid, becomes liable for negligence once the provision of aid is undertaken. ${ }^{45}$ Similarly, a landlord who voluntarily performs repairs not required by law will be held responsible for injuries resulting from his failure to proceed with due care. ${ }^{48}$ Insofar as an actor fails to meet the standard of due care, his or her conduct may be deemed tortious.

Case law has firmly established that the standard of due care is breached whenever a provider of aid exposes a recipient of aid to reasonably foreseeable harm. Thus, the Restatement of Torts explains: "If the actor has succeeded in removing the other from a position of danger to one of safety, he cannot change his position for the worse by unreasonably putting him back into the same peril, or into a new one."17 This aspect of due care underlines the continuous nature of the responsibility. ${ }^{48}$ The pro-

44. Glanzer v. Shepherd, 233 N.Y. 236, 236, 135 N.E. 275, 276 (1922) (Cardozo, J.).

45. See, e.g., Devlin v. Safeway Stores, 235 F. Supp. 882 (S.D.N.Y. 1964) (slip victim negligently escorted home); $c f$. Jackson v. City of Joliet, 715 F.2d 1200, 1202 (7th Cir. 1983) ("[I]f you do begin to rescue someone you must complete the rescue in a nonnegligent fashion even though you had no duty of rescue in the first place.").

46. See, e.g., Conner v. Farmers \& Merchants Bank, 243 S.C. 132, 132 S.E.2d 385 (1963); see also infra note 47 (discussing similar case).

47. Restatement (SeCOND) of ToRTs $\S 324$ comment $g$ (1965); $c f$. Marks v. Nambil Realty Co., 245 N.Y. 256, 259, 157 N.E. 129, 130 (1927):

The tenant does not have to prove that by the negligent making of the repairs what was wrong has been made worse. His case is made out when it appears that by reason of such negligence what was wrong is still wrong, though prudence would have made it right. . . . [T] ence of the prop cloaked the defect, dulled the call to vigilance, and so aggravated the danger.

48. Of course, the responsibility is not infinitely continuous, thereby obligating the gratuitous provider of aid to an unreasonable length of good conduct. Instead, what is required is that a provider of gratuitous, direct aid make a reasonable attempt to avoid reasonably foreseeable harm. 
vider of aid is legally barred from simply abandoning the recipient; instead, the circumstances of release must be considered along with their potential prospective effect on the recipient being released. ${ }^{49}$ This principle has been articulated in many varied areas of the law, including cases involving train safety, ${ }^{50}$ police conduct, ${ }^{51}$ and medical malpractice. ${ }^{52}$

\section{B. Application}

In the context of deinstitutionalization, the fundamental claim suggested by the common law is that the state has a duty to proceed with due care in the process of patient discharge. The state assumes this duty once it institutionalizes a patient and thereby commences a relationship of aid. ${ }^{53}$

49. See, e.g., Parvi v. City of Kingston, 41 N.Y.2d 553, 362 N.E.2d 960, 394 N.Y.S.2d 161

(1977) (issue of negligence where drunkard taken into police custody was eventually released to abandoned golf course near busy thruway).

50. In Haug v. Great N. Ry. Co., 8 N.D. 23, 27, 77 N.W. 97, 99 (1898), the North Dakota Supreme Court observed:

When the carrier discovers that one helpless from intoxication is upon its train without right, it must, in selecting a safe place to put him off, have regard to his actual condition, physical and mental. . . . The law declares to the carrier that it shall not expose him to great peril, even in exercising its undoubted right to eject him; and, in declaring whether he will be subjected to peril, not only must climatic conditions, the propinquity of shelter, and other matters be taken into account, but also the actual state of his mind and bodily health and strength, if known to the agent of the carrier.

See also Cincinnati N.O. \& T.P. Ry. Co. v. Marrs' Adm'x, 119 Ky. 913, 85 S.W. 188 (1905) (defendant railroad company obliged to see drunk left by another railroad safely out of yard).

51. E.g., Iglesias v. Wells, 441 N.E.2d 1017, 1020 (Ind. App. 1982):

[T] he case at bar presents a unique question of law because [previous cases] involved situations where the injured prisoners were in the supervising authority's custody when their injuries occurred. Iglesias's injuries occurred after he was released from Sheriff Wells' custody and he argues his injuries were caused by the circumstances of his release. There is little law on this point; however, the authorities which are available lead us to conclude that under some circumstances [here, adverse weather conditions] the Sheriff would owe Iglesias a duty to release him in a manner which would not subject him to unreasonable danger.

See also Schuster v. City of New York, 5 N.Y.2d 75, 86-89, 154 N.E.2d 534, 541-42, 180 N.Y.S.2d 265, 274-76 (1958) (McNally, J., concurring) (state's assumption of relationship with voluntary police informant carries with it obligation to exercise reasonable prudence with regard to foreseeable risks); supra note 49.

52. Medical malpractice has long recognized the tort of "abandonment," a cessation of treatment already underway, including failure to provide follow-up services outside of the hospital when necessary. See, e.g., Baldor v. Rogers, 81 So. 2d 658 (Fla. 1954) (physician held negligent for discharging lip cancer patient without providing for further medical attention); Fausette v. Grim, 193 Mo. App. 585, 186 S.W. 1177 (1916) (patient released from hospital with postoperative insanity later became violently insane due to excitement and disturbance upon release); Gross v. Partlow, 190 Wash. 489, 68 P.2d 1034 (1937) (surgeon held liable for discharging patient with lower bowel condition and then ceasing to treat plaintiff after he had returned home); infra notes 53, 57-58 (discussing additional cases); Hospitals Expanding Procedures to Assist Patients for Discharge, N. Y. Times, Feb. 11, 1988, at B9, col. 1. (summarizing statement by Society for Hospital Social Work Directors):

[1]f a patient is discharged with a wound that requires regular cleaning and dressing but the hospital makes no arrangements for follow-up care, it might be held legally responsible for negligent discharge if the patient develops an infection . ... .

"The hospital has a duty to take reasonable steps to protect a discharged patient from dangers which are reasonably foreseeable." [lawyers' monograph].

See generally Annotation, Liability of Physician Who Abandons Case, 57 A.L.R.2D 432 (1958 \& Supps. 1984, 1988) (collecting cases).

53. See, e.g., St. George v. State, 203 Misc. 340, 349, 118 N.Y.S.2d 596, 604 ("The State, having assumed to care for and treat a mental incompetent confined to its care . . . was obliged to exercise a 
The absence of a direct constitutional or statutory mandate simply implies that the state has no original affirmative obligation to provide minimally adequate discharge planning and an acceptable aftercare environment. ${ }^{54}$ However, once the state does commence a relationship with the patient, it becomes-like the good samaritan-bound by the duty to proceed with due care.

The state tortiously breaches this duty whenever its institutions expose their patients to reasonably foreseeable harm..$^{55}$ Such a tort arises where the state, after having undertaken to provide aid to the patient, simply abandons him or her upon discharge, without regard to the conditions the patient is likely to encounter in the post-discharge environment. The same tort occurs even in those cases where patient release is mandated by statute: Any instance of release-whether or not required by law-may not be conducted unreasonably, and may be deemed tortious insofar as it violates basic standards of care. ${ }^{\text {s8 }}$

These principles have been applied previously in cases involving physician and hospital liability as well as mental health practice. Medical malpractice has traditionally included a tort of "abandonment" where services commenced have been discontinued, or where necessary follow-up care

reasonable degree of care."), rev'd on other grounds, 283 A.D. 245, 127 N.Y.S.2d 147, affd, 308 N.Y. 681,124 N.E.2d 320 (1953). The duty to proceed with due care may be triggered by even the slightest undertaking on the part of the provider of aid. See, e.g., Bourgeois v. Dade County, 99 So. 2d 575 (Fla. 1958) (by virtue of cursory preliminary examination, after which hospital decided it was not necessary to admit patient, hospital became subject to duty of due care which it breached by releasing patient); O'Neill v. Montefiore Hosp., 11 A.D.2d 132, 202 N.Y.S.2d 436 (1960) (where receiving nurse refused to admit patient but telephoned for help elsewhere, such brief contact was sufficient to create issue of negligence).

54. Youngberg states that "[a]s a general matter, a State is under no constitutional duty to provide substantive services for those within its border." 457 U.S. 307,317 (1982).

55. Studies have indicated that an unstructured release without referral to a community aftercare or transitional service will result in a predictable and substantial increase in the rate of reinstitutionalization. See H. Freeman \& O. Simmons, The Mental Patient Comes Home (1963); Zolik, Lance \& Sommers, Hospital Return Rates and Pre-Release Referrals, 18 ARCHIVEs GEN. PsYchIATRY 712 (1968).

Mentally ill patients are exposed to reasonably foreseeable harm whenever they are released to unstructured, unsupervised, shelterless environments where their condition will usually deteriorate. See J. TalbotT, The Homeless Mentally Ill (1984); $c f$. McCain v. Koch, 117 A.D.2d 198, 211, 502 N.Y.S.2d 720, 728 (1986), rev'd on other grounds, 68 N.Y.2d 713, 497 N.E.2d 679, 506 N.Y.S.2d 312 (1986) (denial of appropriate emergency shelter to homeless families constitutes irreparable injury). Where individuals have been released to foreseeably dangerous circumstances, the act of release itself, rather than the mental or physical state of the individual or the conditions of the release environment, has been held to be the proximate cause of the injuries that ensue. Parvi v. City of Kingston, 41 N.Y.2d at 560, 362 N.E.2d at 965,394 N.Y.S.2d at 166; see also infra notes 57-58 and accompanying text (discussing other cases where act of release established tort liability).

56. The statutory obligation to release a patient does not trump the common law obligation to undertake such a release with due care. Rather, these two aspects of the law should complement each other to make sure both that 1) discharge takes place, pursuant to the statute, and that 2) it takes place in a safe and responsible way, pursuant to the requirements of due care.

It should be stressed, moreover, that the statutory framework providing for mandatory release of capable patients was developed as part of an entire project. The rationale behind deinstitutionalization was not simply that patients should be released, but that they should be released to suitable forms of community care. In that sense, the intention of the release statutes coincides with the common law goal to ensure that follow-up services are provided in the post-discharge environment. 
has not been provided. ${ }^{57}$ Moreover, negligence has similarly been established where state psychiatric hospitals have released potentially unstable individuals to unsupervised, unstructured environments where they have caused injury to themselves or to others. ${ }^{88}$ Together, these cases lay the conceptual and precedential foundation necessary to extend the application of fundamental tort principles to the situation of negligent patient release, ${ }^{59}$ where the reasonably foreseeable harm is mental and physical deterioration due to inadequate discharge planning and a lack of community resources. ${ }^{60}$

The patient release process is complex, and the specific parameters of due care are difficult to define in the abstract without a trial process. However, in the clearest and most significant cases of negligence-such as where hospitals have made no reasonable attempt to locate and arrange some form of community aftercare services prior to a patient's discharge, but instead have simply released the patient directly to city streets-the common law can be most effective in recognizing violations of due care. ${ }^{61}$ Such cases should therefore provide a starting point for advocates and

57. See supra note 52 (discussing abandonment); see also, e.g., Le Jeune Road Hosp. v. Watson, 171 So. 2d 202 (Fla. Dist. Ct. App. 1965) (quoting Health LAW CENTER OF THE UNrversity of Pittsburgh, Hospital Law Manual (1960)) ("Once a hospital begins to treat a person, it must not act unreasonably in having him removed from the premises. . . if it is foreseeable that his condition will be aggravated or his danger increased by removal."); Christy v. Saliterman, 288 Minn. 144, 158, 179 N.W.2d 288, 298 (1970) (citing and affirming lower court) ("psychiatrist who discharges from hospitalization a patient ... is obligated to take . . . reasonable precautions . . . to obviate or minimize the patient suffering harm after discharge because he was not prepared or competent to care for himself or because suitable arrangements had not been made to provide proper continued care for him.").

58. See, e.g., Bell v. New York City Health \& Hosps. Corp., 90 A.D.2d 270, 456 N.Y.S.2d 787 (1982) (citing numerous authorities where claims of psychiatric malpractice have involved nature of decision to release, court held state psychiatric hospital liable for negligent release of patient who attempted suicide); Comiskey v. State, 71 A.D.2d 699, 418 N.Y.S.2d 233 (1979) (involving patient suicide) ("[T]he State . . . is required to exercise reasonable care in . . . supervising and protecting mentally deficient persons to prevent injury to themselves and others.").

59. In a related article, working solely with New York law, one commentator has suggested that funds to build shelters for the homeless could be generated by suing institutions for faulty medical treatment provided to deinstitutionalized homeless during their stays in institutions, including the malpractice tort of premature discharge. Note, Establishing a Right to Shelter for the Homeless, 50 BROOKLYN L. REv. 939, 984-94 (1984). What must be stressed, however, is the type of activity that takes place at the point when discharge is mature-whether adequate discharge planning takes place, whether a significant effort is made to locate and arrange for some form of community follow-up and supervision.

60. Similar principles are implied in Justice Blackmun's concurrence in Youngberg. He speculates that it may be

necessary to prevent a person's pre-existing self-care skills from deteriorating because of his commitment. . . . If a person could demonstrate that he entered a state institution with minimal self-care skills, but lost those skills after commitment because of the State's unreasonable refusal to provide him training, then, it seems to me, he has alleged a loss of liberty. . . .

457 U.S. at 327 . This logic can be extended to suggest that a state must undertake similar efforts to prevent the patient from deteriorating upon release. Of course, Justice Blackmun's argument is based on constitutional doctrine; it is limited to preventing deterioration only within the institutional setting. One must turn to the common law to make a similar argument about deterioration after discharge.

61. See supra note 25 (discussing instances of such abuse), note 55 (discussing harm). 
courts, leaving other less apparent instances of negligence for subsequent decisions once basic principles and doctrine have been established.

It should be stressed that, even where patients are not simply abandoned, but instead are provided the minimal resources that patients more typically receive-such as medications, instructions for their use, and a list of possible housing alternatives-there is still no guarantee that an unstable patient will adhere to the medical regimen or succeed in finding an appropriate residence. ${ }^{62}$ Therefore, what is ultimately needed to make a policy of deinstitutionalization efficacious is a network of outreach services and community aftercare facilities that make consistent attempts to maintain contact with released patients and to provide some structure for their treatment outside of institutional walls. Theoretically, negligence could be broadly ascribed to all instances where these services are lacking, for in such cases state actors release those for whom they have become responsible to situations that, absent necessary safeguards, expose dischargees to foreseeable harm. However, such a concept of negligence may be too broad for courts to apply in the first instance without raising questions of judicial legitimacy. Thus, this Note advocates taking as a starting point only those situations in which not even minimal or nominal aid has been provided to patients being released. However, it is toward this broader conception of negligence that the common law must over time mature.

Since the state employs the doctors and staff involved in the discharge process at state psychiatric institutions, advocates representing mentally ill persons could bring causes of action for negligent patient release against the state through respondeat superior ${ }^{63}$ As a threshold matter, each suit will depend on the extent to which the state involved has immunized itself and its agencies against tort. ${ }^{64}$ Suits could be brought either on behalf of

62. Cf. Kanter, supra note 1, at 81 ; Rubenstein, supra note 21, at $386 \mathrm{n} .45$ (low income patients often provided only medication and evaluation).

63. Since the state is responsible for overseeing the overall provision and delivery of mental health care services, it is more practical from the point of view of reform to bring suits against the state itself rather than against individual doctors. One traditional legal means for bringing such suits is respondeat superior. Cf. Morell v. Balasubramanian, 70 N.Y.2d 297, 301, 514 N.E.2d 1101, 1102, 520 N.Y.S.2d 530, 531 (1987) ("A suit against a State officer will be held to be one which is really asserted against the State when it arises from actions or determination of the officer made in his or her official role and involves rights asserted ... solely against the State."). For examples of liability imposed on state actors, see Maroon v. State, 411 N.E.2d 404, 417 (Ind. App. 1980) (state not immune from liability for damage caused by escapee of state mental hospital); Austin W. Jones Co. v. State, 122 Me. 214, 119 A. 577 (1923) (state held liable under respondeat superior where negligently released mental patient set plaintiff's property ablaze); State v. Brosseau, 124 N.H. 184, 470 A.2d 869 (1983) (sovereign immunity does not bar suit for wrongful discharge of psychiatric patient); see also supra notes 53,58 , infra note 75 (discussing cases brought against state mental hospitals).

64. The movement away from immunity and toward governmental accountability has accelerated in this century with the passage of state and federal tort claims acts. All but a few states have either totally or partially abolished their sovereign immunity. House COMM. ON THE JUdICIARY, JUDICIAL Review-Agency Actions, H.R. ReP. No. 1656, 94th Cong., 2d Sess., reprinted in 1976 U.S. Code Cong. \& ADmin. News 6121. Although many states continue to protect themselves from liability in the performance of judicial and legislative functions, usually certain ministerial acts, as opposed to basic policy and planning decisions, will not fall within the grant of immunity covering official action. See, e.g., Bellavance v. State, 390 So. 2d 422 (Fla. App. 1980) (applying this principle 
released patients who have been provided with no aftercare plans, or on behalf of institutionalized patients soon to be released where there are indications that only inadequate community facilities are available. ${ }^{65}$

Difficult situations may arise where voluntary inpatients request and insist upon release even after doctors have apprised them of limited community resources and of the significant dangers posed by inadequate discharge environments. ${ }^{86}$ Can the state be held liable once the decision to be discharged has been made by the patient, fully aware of the options, exercising what amounts to an "informed consent"? ${ }^{67}$ Presenting the patient with a Hobson's choice between institutional confinement and squalid homelessness should not shield the state and its actors from charges of negligence. Released patients, even those who have presumably "consented" to their release, should maintain the right to sue when the legally required release fails to conform to a standard of due care. ${ }^{68}$ Once the

in context of release of mental patient).

65. Suits aimed toward equitable or prospective relief would probably be most effective in terms of generating new structures and mechanisms to guarantee the provision of adequate mental health care services in the community.

A common law cause of action was brought by the Coalition for the Homeless, on behalf of dischargees from state psychiatric care facilities, against the governor of New York. Klostermann v. Cuomo, 126 Misc.2d 247, 481 N.Y.S.2d 580 (1984). In addition to statutory and constitutional claims, Count VII of the complaint charged defendants with violating "their common law duty to provide state hospital patients with reasonable care and to protect them from reasonably foreseeable harm." 126 Misc. 2d at 260, 481 N.Y.S.2d at 585. The Supreme Court of New York County dealt only briefly with this claim, since it denied jurisdiction. Id. However, Judge Wallach did cite two cases to suggest that similar claims had been rejected in the past: Riss v. City of New York, 22 N.Y.2d 579, 240 N.E.2d 860, 293 N.Y.S.2d 897 (1968); and Perazzo v. Lindsay, 23 N.Y.2d 764, 244 N.E.2d 471, 296 N.Y.S.2d 957 (1968). The Court's analysis addressed none of the mental health cases discussed in this Note, and the only authorities it did cite were inapposite; neither Riss nor Perazzo discusses the standard of care owed by public officials to mentally disabled persons under their care and custody.

66. Voluntary patients must usually request release through written applications. In some states, statutes permit the institution to detain the patient for several days. See, e.g., Fla. STAT. ANN. \$ 394.465(2)(a) (West 1973 \& Supp. 1981) (three days); OKLA. STAт. ANN. tit. 43A § 73 (West 1979) (ten days), recodified at 43A $\S \S 7-101$ to 7-102 (Supp. 1988). One reason for this detention, aside from allowing the patient to change his mind or allowing the hospital to commence involuntary commitment proceedings, is to provide the staff with an opportunity to negotiate for some transitional care or aftercare in the community. S. BRAkel, J. PARRY \& B. WeINER, supra note 42, at 185.

67. The patient's release decision will often fall short of the paradigm required by informed consent. When one alternative presented to the patient is prolonged institutionalization, the patient cannot be described as making a free choice among proper medical alternatives. Rather, the patient is responding to the threat of coercion raised by the prospect of further confinement. Cf. Friedman, Legal Regulation of Applied Behavior Analysis in Mental Institutions and Prisons, 17 AR1z. L. REv. 39, 82 (1975) (describing confinement as variable that affects voluntariness of person's acts). Arguably, this coercive influence renders meaningless the concept of consent.

A state's retreat to a doctrine of informed consent would, to some extent, be bitterly ironic. In other areas of mental health practice, states have only begrudgingly recognized the right of patients to determine the course of their own treatment. In establishing the right of patients to refuse medication, for example, the battle to adopt a doctrine of consent has been particularly hard-fought. See Brooks, Right to Refuse Antipsychotic Medications: Law and Policy, 39 RUTGERS L. REv. 339 (1987); see also supra note 10 (discussing related case law).

68. The signing of "voluntary" release forms is not tantamount to signing a waiver of one's legal rights to sue in tort. Courts have upheld the claims of mental patients and their families who have sued for negligent release. See, e.g., Poss v. Georgia Regional Hosp., 676 F. Supp. 258 (S.D. Ga. 1987) (where suicidal patient killed himself after discharge, hospital held liable despite various claims 
state has assumed a duty of care, it may not exercise total latitude in meeting the patient's release request, but must provide meaningful and medically acceptable alternatives for those patients who seek relocation in community settings. $^{\text {e日 }}$

The Supreme Court implicitly encouraged this shift away from constitutional adjudication and toward a common law approach in Youngberg. Although the Court set out to determine the rights of institutionalized patients under the Fourteenth Amendment, ${ }^{30}$ it ultimately deferred to "professional judgment" to determine the content of those rights. ${ }^{71}$ In holding that the "proper standard for determining whether a State adequately has protected [mental patients'] rights" turns on whether a "professionally acceptable" medical choice has been made, ${ }^{72}$ the Court tacitly adopted a tort law conceptualization of the rights of mentally disabled patients. ${ }^{73}$

\section{Legislative and Institutional Response}

While common law rulings provide a concrete remedy to those who seek judicial redress, their long-term significance lies in their ability to provide an impetus for reform to be carried out through other branches of government. In order to develop a sense of the consequences of using the common law in the context of deinstitutionalization, it is important to consider the range of probable legislative and institutional responses to com-

of sovereign and governmental immunity); Bell v. New York City Health \& Hosps. Corp., 90 A.D.2d 787, 456 N.Y.S.2d 787 (1982) (psychiatric hospital held liable for negligence where released patient attempted suicide). Other cases have denied the right of doctors and hospitals to contract against negligence. See Kozan v. Comstock, 270 F.2d 839 (5th Gir. 1959); Tunkl v. Regents of Univ. of Cal., 60 Cal. 2d 92, 383 P.2d 441, 32 Cal. Rptr. 33 (1963).

69. "Since discharges to inadequate environments often trigger relapses, and since accepted medical practice today is to move the patient gradually from a more structured environment to a less restrictive one, appropriate treatment should include aftercare in the community." Rhoden, supra note 12 , at 421 . The revision of state mental health codes in the 1970's has made it clear that, even though community facilities are lacking, many states at least recognize the importance of least restrictive placement. S. BRAKEL, J. PARRY \& B. WeInER, supta note 42, at 266 . Common law courts, experienced in discerning and applying the concepts prevalent in the existing legal topography, can prompt the states to take seriously their latent commitment to meeting the demands of accepted medical practice.

70. 457 U.S. 307,314 (1982).

71. Observing that "interference by the federal judiciary with the internal operations of these institutions should be minimized," the Court limited the role of judicial review to determining whether in fact an acceptable professional judgment had been made. Where such judgments have been made, patients' liberty interests under the constitution have not been infringed. 457 U.S. at 321-23.

72. Id. at 321. "Liability may be imposed only" for "substantial departure from accepted professional judgment, practice or standards." Id. at 323.

73. Indeed, Chief Judge Seitz, in his concurrence in the court of appeals case, tellingly observed:

Distinguishing constitutional violations from ordinary malpractice claims is especially difficult

in the present case. . . [ [W]ith respect to the institutionalization of the developmentally disabled, the Constitution only establishes minimum standards below which the state's conduct may not fall. Although common-law tort principles may provide a useful starting point in formulating the appropriate standard of care . . . they cannot be determinative of the constitutional issue.

Romeo v. Youngberg, 644 F.2d 147, 177-78 (3d Cir. 1980) (Seitz, C.J., concurring), vacated and remanded 457 U.S. 307 (1982). 
mon law adjudications involving patient discharge. Major issues to be considered include the extent to which common law remedies can be pursued effectively in light of the possibility of statutory reinstatement of immunity and in light of possible adverse effects on institutional process.

\section{A. Statutory Immunity}

A legislature opposed to the application of common law tort standards in the context of patient release could respond strongly by creating statutory immunity for state doctors and hospitals involved in the discharge process. A grant of total immunity, for example, could severely undercut the practical objectives of common law rulings.

There are, however, legal and practical restraints that reduce the capacity of legislatures to respond in such a peremptory way. As a general rule, legislatures may not abrogate common law rights without providing for some alternative means of remedy through statute. This principle is embodied in the "right to remedy" clauses of many state constitutions, ${ }^{74}$ which make it unconstitutional to abolish completely a common law right. Courts have persistently enforced right to remedy clauses in responding to legislative attempts to limit the possibility of judicial redress. ${ }^{75}$ In turn, legislatures have sought to avoid constitutional impasses either by creating alternative statutory remedies or by enacting statutes that provide for only qualified, rather than total, immunity-preserving the possibility of judicial redress in those cases where negligence is most apparent. ${ }^{76}$

74. The various "right to remedy" provisions range from ARIz. ConST. art. 18, § 6: "The right of action to recover damages for injuries shall never be abrogated, and the amount recovered shall not be subject to any statutory limitation"; to the more broadly worded InL. CoNST. art I, $\$ 12:$ "Every person shall find a certain remedy in the laws for all injuries and wrongs which he may receive ...."; see also, e.g., Conn. Const. art. I, § 10; FLA. ConST. art. I, § 21; MASS. Const. pt. I, art. 11; N.C. ConsT. art. I, $\S 18$; PA. ConsT. art. I, $\S 11$. For further examples from other states, see cases cited infra notes 75-76.

75. See, e.g., Stewart v. Houk, 127 Or. 589, 271 P. 998 (1928) (statute removing tort liability of automobile drivers to gratuitous guests held unconstitutional violation of right to remedy clause); Lebohm v. City of Galveston, 154 Tex. 192, 275 S.W.2d 951 (1955) (city ordinance abrogating municipal liabilities for injuries sustained on streets and sidewalks unconstitutional); see also Note, Torts-North Carolina's "Good Samaritan" Statute, 44 N.C.L. REv. 508 (1966) (considering constitutionality of statute granting immunity).

For a case concerning doctor and hospital liability, see State v. Brosseau, 124 N.H. 184, 197, 470 A.2d 869, 876-79 (1983) (special concurrence) (right to remedy clause would render immunity unconstitutional in context of four consolidated claims involving mental health practice, including one for negligent release); see also Note, Good Samaritans and Liability for Medical Malpractice, 64 Colum. L. REv. 1301 (1964) [hereinafter "Note, Good Samaritans"].

Any attempt to abrogate the right to sue for malpractice will in all likelihood be struck down in many jurisdictions . . . . Total immunity for doctors might be struck down as unconstitutional, particularly in states with a right to a remedy provision; moreover, even if sustained, immunization could very well fail to secure the desired objective. Id. at 1315-21 (citations omitted).

76. See, e.g., Roberson v. Roberson, 193 Ark. 669, 101 S.W.2d 961 (1937) (limiting right of guest passengers to recover from driver to cases where driver's conduct was wanton and willfull); see also Note, Good Samaritans, supra note 75, at 1308 (statutory grants of immunity are invariably qualified for good samaritans). 
The particular legislative response will depend, to a large extent, on the degree to which courts are willing to recognize negligence in various aspects of the patient discharge process. Where courts proceed incrementally, as the unique methodology of the common law demands, beginning by recognizing liability only with regard to the clearest and most significant examples of negligence, legislatures will be less likely to respond defensively and more likely to concede that flagrant violations should be deterred by judicial means.

\section{B. Effects on Institutionalization and Deinstitutionalization}

A different legislative or institutional response would be to avoid liability from the outset by passing statutes and guidelines that limit the initial admission of patients to state psychiatric facilities. In other words, the threat of common law rulings against the state could result in reduced access to institutional care. This possibility, while serious, poses only a slightly greater threat to patients than the status quo. Currently, the lack of sufficient aftercare and community facilities severely curtails whatever benefits accrue from the initial, usually brief institutional stay. ${ }^{77}$ Hospitals release many patients to unstructured environments where their mental conditions deteriorate until they require reinstitutionalization, after which they are then released again - the familiar syndrome of the "revolving door." 78 Judicial pressure, generated through the common law, is necessary to achieve reforms in the post-discharge environment, so that ultimately the benefits of institutionalization, rather than dissipating soon after release, will endure as patients return to less restrictive settings. ${ }^{79}$

Alternatively, legislatures and institutions could respond to the threat of tort liability by enacting statutes and guidelines that restrict patient discharge. Such a response would create short-term disequilibria in the institutional setting, prolonging hospital stays for current patient populations, thereby decelerating deinstitutionalization until necessary reforms occur at the community level. The prospect of this response raises serious dilemmas for a society concerned both with liberty and with the right of individuals to be afforded reasonable care. Neither alternative-continued release to inadequate environments or decelerated deinstitutionalization-is completely satisfactory. The common law, like its constitutional and statutory alternatives, cannot neatly avoid this Scylla and Charybdis of the mental health field.

Although this tension can never be averted absolutely, several factors will combine to mitigate the propensity of legislatures to respond by im-

77. See supra note 55 and text accompanying notes 18-25.

78. See Caton \& Goldstein, supra note 24; Solomon, Davis \& Gordon, Discharged State Hospital Patients' Characteristics and Use of Aftercare: Effect on Community Tenure, 141 AM. J. PsYchiATRY 1566 (1984).

79. See Solomon, Davis \& Gordon, supra note 78. 
posing unnecessarily restrictive guidelines on the discharge process. First, the judiciary is likely to exercise its own independent controls to curtail unwarranted liability. For instance, as has been the rule in prior cases involving wrongful release, courts will generally not impose liability where there have been honest errors of professional judgment, but only where the professional made no reasonable attempt to effect a proper release. ${ }^{80}$ Secondly, courts may tailor remedies in favor of prospective and equitable relief as opposed to compensatory damages. Without the financial risk of heavy tort liability, institutions may be less likely to react defensively by unnecessarily prolonging patient stays.

Finally, because community care is often less expensive than institutional alternatives, it will be fiscally more efficient for legislatures in many jurisdictions to avoid liability by creating increased community services rather than by restricting institutional discharge. ${ }^{81}$ In many states, the resources necessary to develop more substantial community alternatives could be effectively obtained through a reallocation of existing mental health funds. ${ }^{82}$ In these areas, common law rulings should generate a more cooperative legislative response.

\section{Legislative Accommodation and the Role of Common Law Courts}

Some state legislatures will respond to common law rulings by accommodating judicial concerns and by attempting to cooperate in achieving a more satisfactory provision of community care. This has already been the result of one recent litigation where an effort was made to stress basic requirements and principles of "care" rather than specific statutory mandates. ${ }^{83}$ While the ultimate goal of a common law court may be to obtain

80. See, e.g., Cohen v. State, 51 A.D.2d 494, 497, 382 N.Y.S.2d 128, 130 (1976) (hospital held liable for release of suicidal individual where negligence constituted "more than an error of medical judgment"); Homere v. State, 48 A.D.2d 422, 370 N.Y.S.2d 246 (1975) (state hospital liable for release of violent patient where more than honest error of judgment).

81. See General Accounting Office, supra note 2, at 5-6 (citing seven studies comparing costs of institutional and community care, including HEW study that found average net savings over ten-year period of $\$ 20,800$ per person for community care); Minnesota Department of Public Welfare, Residential Care Study: Executive Summary 38, 88-91, 104 (1979) (community residential and support programs could save state between one and two million dollars per year).

82. See supra note 21 (discussing disproportionate resource allocation), note 41 (discussing political pressures resisting reallocation). Louisiana recently reallocated its funds from institutional to community alternatives. See Deiher, How to Ensure That the Money Follows the Patient: A Strategy for Funding Community Services, 37 Hosp. \& Community Psychiatry 256 (1986).

83. A new litigation strategy was developed for an action on behalf of mentally disabled individuals in Arizona, claiming that they were entitled to a full continuum of coordinated community mental health services. The approach drew from state statutory provisions but emphasized remedies based on broad "principles of care" rather than specific prescriptions. See Arnold v. Sarn, No. C 432435 (Ariz. Super. Ct., Jun. 24, 1985), appeal docketed, No. ICA-CIV 9262 (Ariz. Ct. App., Oct. 3, 1986). Accordingly, a court order was issued requiring the state hospital to ensure that discharged patients had a place to live and an adequate program for necessary treatment. The executive and legislative branches have joined the judiciary's efforts to address the inadequacies in Arizona's system of care. Specifically, the legislature has shown a willingness to increase the level of funding. See Santiago, Gittler, Beigel, Stein \& Brown, supra note 26. 
this form of salutary legislative response, there is still a value in common law rulings even where such complete cooperation cannot be anticipated as an immediate or inevitable result. Common law rulings, even when rejected by the legislature and challenged by contrary statutes, at least retain the valuable effect of articulating individual demands and identifying social goals. ${ }^{84}$ Individuals and politically ineffective groups have traditionally had recourse to the courts where majoritarian bodies have either violated or ignored their concerns. ${ }^{85}$ These concerns, once articulated by the judiciary, often require of the legislature additional consideration and response. ${ }^{86}$

While constitutional decisions have at times transformed entire bodies of law and effected major social change, common law rulings have the advantage of providing a forum for the fair hearing of minoritarian demands without jeopardizing the flexibility of the legislature to respond in ways that reflect its own concerns. ${ }^{87}$ Common law courts develop standards gradually, as precedents are tentatively and cautiously extended over time. ${ }^{88}$ They may begin with de minimis standards, insisting upon legislative recognition of minimal norms. Then, once courts and legislatures have arrived at mutual accommodation, future decisions may suggest reevaluation aimed at higher goals. At each stage, the common law prods the legislature, incrementally, inviting it either to acquiesce in the court's judgment or to insist again on minimal norms through contrary statutes. ${ }^{89}$ In this manner, the common law court maintains an impact on legislative agendas, and both branches are able to play complementary roles in work-

84. "The mentally ill, whether in a State institution or previously institutionalized and now homeless in New York City, are entitled to a declaration of their rights as against the State. . . . [T] $T$ je judiciary is empowered to declare the individual rights in all such cases." Klostermann v. Cuomo, 61 N.Y.2d 525, 530-31, 463 N.E.2d 588, 590, 475 N.Y.S.2d 247, 249 (1984).

85. "TT]he judiciary must respond to the complaints of the aggrieved." Chayes, supra note 40, at 1308. "[O]ne may ask whether democratic theory really requires deference to majoritarian outcomes whose victims are . . . inmates of mental institutions. . . . Unlike the numerical minorities that the courts protected . . . these have no alternative access to the levers of power in the system." Id. at 1315.

86. One function of common law courts is at times to "do no more than create a situation in which conscious legislative reconsideration of the law [is] made likely." G. CALABREsI, supra note 37, at 2. Common law provides a means to "allocate the burden of [legislative] inertia" by having courts suggest when legislatures should take a "second look." Id. at 146-66.

87. Professor Robert A. Burt has explained:

[T]he implications of initial decisions become clear and are shaped and reshaped over time. . . This is not a methodological weakness, a regrettable inefficiency in [the] common law . . . this time-consuming tentativeness is the legitimizing heart of these adjudicatory methods. This methodology is essential for achieving the deliberate, self-consciously reflective process of social aggregation that offers the best prospect of preserving individuals' inviolable integrity within that aggregation and protecting judges against imposing on others their merely idiosyncratic, socially isolated visions of aggregating principles.

Burt, Pennhurst: A Parable, in IN THE INTEREsT OF GHILdREN 265, 356-57 (R. Mnookin ed. 1985).

88. See id.

89. "Judicial participation is not by way of sweeping and immutable statements of the law, but in the form of a continuous and rather tentative dialogue with other political elements." Chayes, supra note 40 , at 1316 . 
ing with complex aspects of the law. Reform is achieved gradually, as interstitial advances cumulate over time.

\section{Conclusion}

The possibility of judicial intervention through the common law merits further attention as a potential means of achieving the mutual goals of widespread patient release and the provision of sufficient aftercare services in the community. ${ }^{80}$ Common law courts may promote reforms in the process of patient discharge and in the subsequent transition to community care by requiring state hospitals and actors to conform to a basic standard of due care. Fundamental principles of duty and care will ultimately enable the judiciary to consider aspects of deinstitutionalization that have yet to be sufficiently addressed under other, traditionally stronger forms of law. The common law, like its statutory and constitutional alternatives, cannot be counted on as a panacea. Instead, it offers at best only a gradual means for the interstitial development of social norms, in part vulnerable to statutory abrogation and other forms of legislative control. Nevertheless, a disciplined application of common law standards in the patient discharge process may enable courts to achieve improved levels of mental health care practice, gradually, without significantly challenging legislative authority and flexibility in the context of a difficult and enduring problem.

90. The idea of employing common law models, especially in areas of law that have come to be dominated almost exclusively by statutes, has been increasingly suggested by recent scholarship. The theoretical foundations for such an approach have been spelled out in Dean Calabresi's A Common LAw FOR THE AGE of Statutes. G. CALABresi, supra note 37. However, Calabresi is primarily concerned with providing a justification for courts to take on an essentially legislative role; his discussion of judicial revision of obsolete statutes is geared toward reconciling judicial action with majoritarian concerns. See, e.g., id. at 92-94 (discussing potential countermajoritarian problems posed by common law courts). This Note suggests that the legitimacy of common law courts also stems from the heightened necessity of representing minoritarian concerns in a legal framework increasingly dominated by statutes and other majoritarian forms of law. 